\title{
Prognostic Significance of Adrenomedullin in Patients with Heart Failure and with Myocardial Infarction
}

Matthew F. Yuyun, MD, MPhil, PhD 1,

Hafid K. Narayan, MD¹,

Leong L. Ng, MD ${ }^{1}$.

Affiliations: ${ }^{1}$ Department of Cardiovascular Sciences, University of Leicester, Leicester and NIHR Leicester Cardiovascular Biomedical Research Unit, Glenfield Hospital, Leicester LE3 9QP, United Kingdom.

Correspondence: Dr Matthew F. Yuyun, Department of Cardiovascular Sciences, University of Leicester, Glenfield Hospital, Leicester LE3 9QP, United Kingdom. Telephone: +44 116250 2449. Email: my85@leicester.ac.uk

\section{Highlights}

- This systematic review shows that adrenomedullin is an independent predictor of death in patients with heart failure, as well as MACE and death in patients who have suffered an acute myocardial infarction.

- Quantification of this peptide might contribute to improved risk stratification in settings of heart failure and myocardial infarction. 


\section{ABSTRACT}

We undertook this systematic review to determine the prognostic significance of adrenomedullin (ADM) in heart failure and acute myocardial infarction (AMI) patients. Given the difficulty in measuring mature ADM, its surrogate, mid-regional proadrenomedullin (MRproADM), has been used in most studies. Systematic search of original published studies via Medline and the Cochrane Collaboration databases restricted to articles in English between $1^{\text {st }}$ of January 1993 to $30^{\text {th }}$ of June 2014 in humans was undertaken. Heterogeneity of studies prohibited a meta-analysis. In heart failure patients, the area under the curve (AUC) for prediction of mortality by MRproADM ranged from 0.68 to 0.81 (95\% confidence intervals $0.63-0.91$ ) across studies. $1 \mathrm{nmol} / \mathrm{l}$ increase in MRproADM was associated with hazard ratios (HR) ranging from 1.77 to 2.79 (95\% confidence intervals (CI) 1.29 - 5.95) for death in heart failure patients. In patients with AMI, the AUC for MRproADM predicting MACE ranged from 0.64 to 0.80 (CI $0.51-0.87$ ) across studies, and death 0.79 to 0.84 (CI $0.73-0.90$ ). $1 \mathrm{nmol} / \mathrm{l}$ increase in MRproADM was associated with HR for MACE ranging from 1.78 to 4.10 (CI 1.20 - 10.12), while log10 of MRproADM had hazard ratios of 3.63 to 9.75 (CI 1.48 - 26.16) for MACE and 4.86 to 16.68 (CI 4.56 - 60.99) for death across studies in AMI patients. In conclusion, adrenomedullin is an independent predictor of death in patients with heart failure, as well as MACE and death in patients who have suffered an AMI. Quantification of this peptide might contribute to improved risk stratification in settings of heart failure and myocardial infarction.

Keywords: Adrenomedullin, myocardial infarction, death, heart failure, coronary artery disease. 


\section{INTRODUCTION}

Adrenomedullin (ADM) is produced from a large peptide precursor molecule (preproadrenomedullin) which consists of 185 amino acids via a two-staged enzymatic process into the mature form with 52 amino acids (1). The gene encoding for adrenomedullin is located within the short arm of chromosome 11 (2). Measurement of mature ADM as biomarker has been previously hampered by its short plasma half-life of $22 \pm 1.6$ minutes, the presence of a binding protein called human adrenomedullin binding protein (AMBP-1) identified as complement factor $\mathrm{H}(3)$, and the immediate binding of ADM to local receptors, which had rendered its accurate measurement difficult to achieve $(3,4)$. A possible solution to this problem came from the development of assays to identify mid-regional pro-adrenomedullin (MRproADM), which is a more stable non-functional fragment of initial precursor peptide, consisting of 45 to 92 amino acids. MRproADM is secreted in stoichiometric amounts to mature $\mathrm{ADM}$ and therefore acts as a reliable surrogate of ADM levels (4). To the best of our knowledge, no study has undertaken a systematic review or meta-analysis of ADM and incident major cardiovascular events or mortality in heart failure patients or acute myocardial infarction patients. We therefore undertook this systematic review with the hope of including a meta-analysis if possible, to determine the prognostic significance of ADM in heart failure patients and in post-acute myocardial infarction patients ( $\mathrm{AMI}$ ).

\section{METHODS}

The methodology was guided by PRISMA (Preferred Reporting Items for Systematic reviews and Meta-Analyses) (5). The inclusion criteria were prospective 
studies published in adult patients with acute or chronic heart failure or acute myocardial infarction or patients presenting with acute dyspnoea or acute chest pain or stable or unstable angina. In addition they must have had adrenomedullin measured at baseline and related to major adverse cardiovascular events or mortality. Excluded were review articles, paediatric studies, and animal studies.

A systematic literature search was carried out on original published studies using Pubmed (Medline) and the Cochrane Collaboration databases using Key words and MeSH terms. For heart failure patients, the MeSH terms or key words were ("Adrenomedullin" OR "ADM" OR "MRproADM") AND "Heart Failure". For myocardial infarction patients, these were ("Myocardial Infarction" OR ( "Angina Pectoris" OR "Angina, Stable" OR "Angina, Unstable") AND ("Adrenomedullin" OR "ADM" OR "MRproADM"). Searches of references of published articles obtained from the above systematic search were also undertaken. The search was restricted to articles published in English between $1^{\text {st }}$ of January 1993 to 30th of June 2014, in humans. Figure 1 shows the flow chart for selection for this systematic review.

The main outcome measure of this systematic review for heart failure patients was death. The outcome measure for myocardial infarction patients was major adverse cardiovascular events (MACE) as primary endpoint measure, with death as secondary endpoint. The endpoint, MACE, was defined variably across studies as a composite of myocardial infarction, stroke, hospitalization for heart failure, and all-cause mortality, although in some studies not all these components were present.

Two authors independently perused all the relevant titles and abstracted data from selected articles with any disagreements settled by a consensus or opinion from 
other co-authors. Some studies had very small sample sizes, but we included given the small number of studies.

Due to the high level of heterogeneity across studies, no quantitative pooling of results from various studies through a meta-analysis was undertaken. This heterogeneity was mainly due the discrepancy in type of adrenomedullin measured (mature ADM versus its surrogate MRproADM), discrepancy in units of ADM used by different studies, the varying use of ADM as a continuous and a categorical variable across studies, the different cut-offs of ADM when used as a categorical variable, and differing logarithmic transformations or unit change of ADM when used as a continuous variable in various statistical models.

\section{RESULTS}

Table 1 shows studies which looked at the relationship between ADM and mortality in heart failure patients. We identified 14 studies in total and these were mainly cohort studies. Baseline plasma levels of MRproADM were significantly higher in patients who died during follow-up compared to those who survived. The area under the curve (AUC) for adrenomellin predicting mortality was only reported for 12 studies using MRproADM in heart failure patients, and this ranged from 0.68 to 0.81 (95\% confidence intervals $0.63-0.91$ ) across studies. Overall the earlier studies using mature adrenomedullin demonstrated a statistically significant association from hazard ratios and 95\% confidence intervals with all-cause mortality $(6,7)$. Subsequent studies using MRproADM showed similar results. When taken as a continuous variable, a 1 nmol/l increase in MRproADM was associated with hazard ratios (HR) ranging from 1.77 to 2.79 (95\% confidence intervals (CI) 1.29 - 5.95) for death in heart failure 
patients. When taken as a $\log 10$ of MRproADM measured in $\mathrm{nmol} / \mathrm{l}$, the hazard ratios ranged from 1.82 to 10.26 for death (95\% CI 1.26 - 80.50). Various cut-offs were used for categorical adrenomedullin as shown in table 1 and these included upper tertile, ROC optimal cut-off, and above the median value. Only one study showed a negative result of MRproADM on mortality in heart failure patients (8).

Table 2 depicts studies which looked at the relationship between adrenomedullin and MACE in acute coronary syndrome patients . We identified 9 cohort studies in total. Baseline plasma levels of MRproADM were significantly higher in patients who experienced a MACE during follow-up compared to those who did not. The AUC for MRproADM predicting MACE ranged from 0.64 to 0.80 (95\% CI 0.51 - 0.87) across studies in AMI patients. When taken as a continuous variable, $1 \mathrm{nmol} / \mathrm{l}$ increase in MRproADM was associated with hazard ratios for MACE ranging from 1.78 to 4.10 (95\% CI 1.20 - 10.12), while log10 of MRproADM had hazard ratios of 3.63 to 9.75 (95\% CI 1.48 - 26.16) for MACE across studies in AMI patients. Only one study showed a negative result of MRproADM on MACE in AMI patients (9). This review also identified studies which have shown that MRproADM significantly enhances the integrated discrimination improvement (IDI) and the net reclassification improvement (NRI) when added to other risk markers like BNP and the Grace Score in AMI patients $(9,10)$. For example, one study showed a NRI of $34.1 \%$ (range $18.6-49.5 \%$ ) for 30-day mortality when MRproADM was added to the Grace score (10).

Table 3 depicts studies which looked at the relationship between adrenomedullin and death in acute myocardial infarction patients . We identified 8 cohort studies in total. The area under the curve (AUC) for MRproADM predicting death 
ranged from 0.79 to $0.84(95 \%$ CI 0.73 - 0.90) across studies in AMI patients. When taken as a $\log 10$ of MRproADM measured in nmol/l, death was associated with hazard ratios ranging from 4.86 to 16.68 (95\% CI 4.56 - 60.99) across studies in AMI patients. One study showed a negative result of MRproADM on mortality in AMI patients (11).

\section{DISCUSSION}

This systematic review has demonstrated that ADM is an independent predictor of death in patients with heart failure. An expanding number of studies have shown diagnostic and prognostic significance of ADM in heart failure patients. Initial crosssectional studies demonstrated that ADM levels were significantly raised in patients with established heart failure compared to controls. ADM is elevated in cardiac failure proportionally to the severity of the disease assessed by NYHA class and to the degree of left ventricular impairment $(9,12)$. ADM also has diagnostic and prognostic value alongside the natriuretic peptides in acute dyspnoea and in chronic heart failure (1220), and in diastolic dysfunction (21). In post-AMI patients with new heart failure (9), patients with established heart failure $(12,22)$, and patients presenting with acute dyspnoea in emergency settings $(13-15,23)$, MRproADM has been shown to have independent prognostic significance for major adverse cardiovascular outcomes. It is also predictive of adverse outcomes in community patients with symptoms of heart failure (24). Our findings therefore highlight the possible usefulness of ADM as a risk stratifying measure in heart failure patients. 
This systematic review has shown that ADM is independently predictive of MACE in patients who have suffered an acute myocardial infarction and strongly support the results of various individual studies. ADM is a known independent predictor of future MACE in coronary disease. It significantly predicts fatal and nonfatal cardiovascular events and all-cause mortality in patients with stable angina (2528), patients with acute coronary syndromes (9-11, 25, 29-34), and patients presenting with acute chest pain (35-37). Our findings corroborate the above observations and help to enhance the importance of ADM as prognostic marker in acute coronary syndromes independent of other established risk markers like the GRACE score and natriuretic peptides. Initial studies used free mature ADM to relate to cardiovascular outcomes $(11,29,31)$, while more recent studies have used the surrogate MRproADM to study this relationship $(9,10,25,26,30,35-37)$. We have reported on the few results for mature ADM. Although we acknowledge that the reliability of some of these results might be questionable due to known problems with mature ADM detection given its short half life, the studies using mature ADM did show a consistent significant prognostic effect on outcomes. Majority of the studies identified in this systematic review used MRproADM, which given the reliability of its measurement should remain the main contemporary method of detecting this peptide.

There were only three negative studies identified in this systematic review for ADM and some outcomes (mortality in heart failure (8), MACE in AMI (9), and death in AMI (11)) and these could be attributed to small sample sizes, or broadening of composite endpoint to include softer outcomes or shorter duration of follow-up of the studies. A net reclassification improvement and integrated discrimination improvement have been observed with the addition of MRproADM into risk assessment models of mortality in patients with acute coronary syndromes $(9,10)$. 
Abundant evidence has accrued suggesting the important role ADM might be playing in cardiovascular disease. ADM plasma levels are increased in atherosclerosis in coronary and peripheral circulation, and there is augmented expression with severity of plaque formation/stenosis and degree of ischemic heart disease syndromes, e.g. less expression in patients with stable angina compared to unstable angina. ADM is significantly raised in acute myocardial infarction, and correlates with severity of AMI (38). ADM levels in acute myocardial infarction are independently associated with subacute left ventricular systolic dysfunction via ejection fraction measurements (29). Intravenous ADM infusion to AMI patients significantly reduces infarct size and prospectively reduces regional wall motion abnormality on cardiac magnetic resonance imaging. ADM levels in community patients with pre-existing cardiovascular disease are predictive of long-term adverse cardiovascular outcomes (39). ADM is associated with degree of systemic hypertension, and pulmonary hypertension and also correlates with functional outcomes in ischemic stroke patients. ADM plasma levels increase with increasing degree of renal impairment (2).

Actions of adrenomedullin are generally protective to organs and tissues, from vasodilation, natriuresis, diuresis, to anti-inflammation (2). The receptors of ADM are a complex of receptor-activity modifying proteins (RAMP) and calcitonin receptor-like receptor (CRLR) (40). The mechanisms of action of ADM are thought so far to be through the generation of nitric oxide via nitric oxide-cyclic guanine monophosphate pathway or through increased intracellular cyclic adenosine monophosphate which activates protein kinase $\mathrm{A}$ which then activates nitric oxide synthase or through 
phosphatidylinositol kinase -3 activation and Akt phosphorylation resulting in enhanced stimulation of endothelial nitric oxide synthase $(2,38)$.

The marked heterogeneity mainly due to discrepancy in adrenomedullin measures across studies prohibited the quantitative combination of data through a meta-analysis. This was a major limitation of the systematic review. Another limitation was the small sample size of some studies and the small number of outcome events in some studies. The variability in study design when including several studies, specifically regarding the definition of MACE as outcome which varied across studies remains a challenge that needs to be considered when performing a systematic review.

Conflicts of interest: None declared. 


\section{REFERENCES}

1. Kitamura K, Kangawa K, Kawamoto M, Ichiki Y, Nakamura S, Matsuo H, Eto T. Adrenomedullin: A novel hypotensive peptide isolated from human pheochromacytoma. Biochem Biophys Res Commun 1993;192:553-560.

2. Ishimitsu T, Ono H, Minami J, Matsuoka H. Pathophysiologic and therapeutic implications of adrenomedullin in cardiovascular disorders Pharmacol Ther 2006;111:909-927.

3. Pio R, Martinez A, Unsworth EJ, Kowalak JA, Bengoechea JA, Zipfel PF, Elsasser $\mathrm{TH}$, Cuttitta F. Complement factor $\mathrm{H}$ is a serum-binding protein for adrenomedullin, and the resulting complex modulates the bioactivities of both partners. J Biol Chem 2001;276:12292-12300.

4. Struck J, Tao C, Morgenthaler NG, Bergmann A. Identification of an Adrenomedullin precursor fragment in plasma of sepsis patients. Peptides 2004;25:1369-1372.

5. Moher D, Liberati A, Tetzlaff J, Altman DG. Preferred reporting items for systematic reviews and meta-analyses: the PRISMA statement. BMJ 2009;339:b2535. 6. Pousset F, Masson F, Chavirovskaia O, Isnard R, Carayon A, Golmard JL, Lechat P, Thomas D, Komajda M. Plasma adrenomedullin, a new independent predictor of prognosis in patients with chronic heart failure. Eur Heart J 2000;21:1009-1014. 7. Richards AM, Doughty R, Nicholls MG, MacMahon S, Sharpe N, Murphy J, Espiner EA, Frampton C, Yandle TG. Plasma N-terminal pro-brain natriuretic peptide and adrenomedullin: Prognostic utility and prediction of benefit from carvedilol in chronic ischemic left ventricular dysfunction. J Am Coll Cardiol 2001;37:183A.

8. Gegenhuber A, Struck J, Dieplinger B, Poelz W, Pacher R, Morgenthaler NG, Bergmann A, Haltmayer M, Mueller T. Comparative evaluation of B-type natriuretic 
peptide, mid-regional pro-A-type natriuretic peptide, mid-regional pro-adrenomedullin, and Copeptin to predict 1-year mortality in patients with acute destabilized heart failure. J Card Fail 2007;13:42-49.

9. Klip IT, Voors AA, Anker SD, Hillege HL, Struck J, Squire I, van Veldhuisen DJ, Dickstein K, investigators O. Prognostic value of mid-regional pro-adrenomedullin in patients with heart failure after an acute myocardial infarction. Heart 2011;97:892-898. 10. Dhillon OS, Khan SQ, Narayan HK, Ng KH, Struck J, Quinn PA, Morgenthaler NG, Squire IB, Davies JE, Bergmann A, Ng LL. Prognostic value of mid-regional proadrenomedullin levels taken on admission and discharge in non-ST-elevation myocardial infarction: the LAMP (Leicester Acute Myocardial Infarction Peptide) II study. J Am Coll Cardiol 2010;56:125-133.

11. Richards AM, Nicholls MG, Yandle TG, Frampton C, Espiner EA, Turner JG, Buttimore RC, Lainchbury JG, Elliott JM, Ikram H, Crozier IG, Smyth DW. Plasma Nterminal pro-brain natriuretic peptide and adrenomedullin: new neurohormonal predictors of left ventricular function and prognosis after myocardial infarction. Circulation 1998;97:1921-1929.

12. von Haehling S, Filippatos GS, Papassotiriou J, Cicoira M, Jankowska EA, Doehner W, Rozentryt P, Vassanelli C, Struck J, Banasiak W, Ponikowski P, Kremastinos D, Bergmann A, Morgenthaler NG, Anker SD. Mid-regional pro-adrenomedullin as a novel predictor of mortality in patients with chronic heart failure. Eur J Heart Fail 2010;12:484-491.

13. Cinar O, Cevik E, Acar A, Kaya C, Ardic S, Comert B, Yokusoglu M, Bilgi C, Meisner M, Madsen T. Evaluation of mid-regional pro-atrial natriuretic peptide, procalcitonin, and mid-regional pro-adrenomedullin for the diagnosis and risk stratification of dyspneic ED patients. Am J Emerg Med 2012;30:1915-1920. 
14. Maisel A, Mueller C, Nowak RM, Peacock WF, Ponikowski P, Mockel M, Hogan C, Wu AH, Richards M, Clopton P, Filippatos GS, Di Somma S, Anand I, Ng LL, Daniels LB, Neath SX, Christenson R, Potocki M, McCord J, Hartmann O, Morgenthaler NG, Anker SD. Midregion prohormone adrenomedullin and prognosis in patients presenting with acute dyspnea: results from the BACH (Biomarkers in Acute Heart Failure) trial. J Am Coll Cardiol 2011;58:1057-1067.

15. Shah RV, Truong QA, Gaggin HK, Pfannkuche J, Hartmann O, Januzzi JL, Jr. Midregional pro-atrial natriuretic peptide and pro-adrenomedullin testing for the diagnostic and prognostic evaluation of patients with acute dyspnoea. Eur Heart J 2012;33:2197.

16. Adlbrecht C, Huelsmann M, Strunk G, Berger R, Moertl D, Struck J, Morgenthaler NG, Bergmann A, Jakowitsch J, Maurer G, Lang IM, Pacher R. Prognostic value of plasma midregional pro-adrenomedullin and C-terminal-pro-endothelin-1 in chronic heart failure outpatients. Eur J Heart Fail 2009;11:361-366.

17. Masson S, Latini R, Carbonieri E, Moretti L, Rossi MG, Ciricugno S, Milani V, Marchioli R, Struck J, Bergmann A, Maggioni AP, Tognoni G, Tavazzi L, Investigators G-H. The predictive value of stable precursor fragments of vasoactive peptides in patients with chronic heart failure: data from the GISSI-heart failure (GISSI-HF) trial. Eur J Heart Fail 2010;12:338-347.

18. Neuhold S, Huelsmann M, Strunk G, Struck J, Adlbrecht C, Gouya G, Elhenicky M, Pacher R. Prognostic Value of Emerging Neurohormones in Chronic Heart Failure during Optimization of Heart Failure-Specific Therapy. Clin Chem 2010;56:121-126. 19. Xue Y, Taub P, Iqbal N, Fard A, Clopton P, Maisel A. Mid-region proadrenomedullin adds predictive value to clinical predictors and Framingham risk score 
for long-term mortality in stable outpatients with heart failure. Eur J Heart Fail 2013;15:1343-1349.

20. Travaglino F, Russo V, De Berardinis B, Numeroso F, Catania P, Cervellin G, Nigra SG, Geraci F, Bressan MA, Guerrini S, Cavazza M, Folli C, Monzani V, Battista S, Mengozzi G, Noto P, Carpinteri G, Semplicini A, Stella F, Ingrassia S, Moscatelli P, Giuntini P, Salerno G, Cardelli P, Di Somma S. Thirty and ninety days mortality predictive value of admission and in-hospital procalcitonin and mid-regional pro-adrenomedullin testing in patients with dyspnea. Results from the VERyfing DYspnea trial. Am J Emerg Med 2014;32:334-341.

21. Xue Y, Taub P, Fard A, Iqbal NM, Nguyen H, Clopton P, Maisel AS. Elevated midregion pro-adrenomedullin is associated with increased mortality in stable outpatients with diastolic dysfunction. Eur Heart J 2011;32:907-908.

22. Bosselmann H, Egstrup M, Rossing K, Gustafsson I, Gustafsson F, Tonder N, Kistorp CN, Goetze JP, Schou M. Prognostic significance of cardiovascular biomarkers and renal dysfunction in outpatients with systolic heart failure: A long term follow-up study. Int J Cardiol 2013;170:202-207.

23. Potocki M, Breidthardt T, Reichlin T, Morgenthaler NG, Bergmann A, Noveanu M, Schaub N, Uthoff H, Freidank H, Buser L, Bingisser R, Christ M, Mebazaa A, Mueller C. Midregional pro-adrenomedullin in addition to b-type natriuretic peptides in the risk stratification of patients with acute dyspnea: an observational study. Crit Care 2009;13:R122.

24. Alehagen U, Dahlstrom U, Rehfeld JF, Goetze JP. Pro-A-type natriuretic peptide, proadrenomedullin, and N-terminal pro-B-type natriuretic peptide used in a multimarker strategy in primary health care in risk assessment of patients with symptoms of heart failure. J Card Fail 2013;19:31-39. 
25. Wild PS, Schnabel RB, Lubos E, Zeller T, Sinning CR, Keller T, Tzikas S, Lackner KJ, Peetz D, Rupprecht HJ, Bickel C, Morgenthaler NG, Papassotiriou J, Tiret L, Munzel T, Blankenberg S. Midregional proadrenomedullin for prediction of cardiovascular events in coronary artery disease: results from the AtheroGene study. Clin Chem 2012;58:226236.

26. Schnabel RB, Schulz A, Messow CM, Lubos E, Wild PS, Zeller T, Sinning CR, Rupprecht HJ, Bickel C, Peetz D, Cambien F, Kempf T, Wollert KC, Benjamin EJ, Lackner KJ, Munzel TF, Tiret L, Vasan RS, Blankenberg S. Multiple marker approach to risk stratification in patients with stable coronary artery disease. Eur Heart J 2010;31:30243031.

27. Sabatine MS, Morrow DA, de Lemos JA, Omland T, Sloan S, Jarolim P, Solomon SD, Pfeffer MA, Braunwald E. Evaluation of multiple biomarkers of cardiovascular stress for risk prediction and guiding medical therapy in patients with stable coronary disease. Circulation 2012;125:233-240.

28. Nishida H, Horio T, Suzuki Y, Iwashima Y, Kamide K, Kangawa K, Kawano Y. Plasma adrenomedullin as an independent predictor of future cardiovascular events in high-risk patients: comparison with C-reactive protein and adiponectin. Peptides 2008;29:599-605.

29. Katayama T, Nakashima H, Honda Y, Suzuki S, Yano K. Relationship between adrenomedullin and left-ventricular systolic function and mortality in acute myocardial infarction. Angiology 2005;56:35-42.

30. Khan SQ, O'Brien RJ, Struck J, Quinn P, Morgenthaler N, Squire I, Davies J, Bergmann A, Ng LL. Prognostic value of midregional pro-adrenomedullin in patients with acute myocardial infarction: the LAMP (Leicester Acute Myocardial Infarction Peptide) study. J Am Coll Cardiol 2007;49:1525-1532. 
31. Nagaya N, Nishikimi T, Uematsu M, Yoshitomi Y, Miyao Y, Miyazaki S, Goto Y, Kojima S, Kuramochi M, Matsuo H, Kangawa K, Nonogi H. Plasma adrenomedullin as an indicator of prognosis after acute myocardial infarction. Hear. 1999;81:483-487. 32. Behnes M, Papassotiriou J, Walter T, Fiedler E, Sauer T, Lang S, Elmas E, Hoffmann U, Borggrefel M, Brueckmann M. Long-term prognostic value of midregional pro-adrenomedullin and C-terminal pro-endothelin-1 in patients with acute myocardial infarction. Clin Chem Lab Med 2008;46:204-211.

33. Walter T, Brueckmann M, Lang S, Sauer T, Fiedler E, Papassotirou J, Behnes M, Elmas E, Borggrefe M, Bertsch T. Comparison of Long-Term Prognostic Value of Nterminal-proBNP and Midregional-pro-Adrenomedullin in Patients with Acute Myocardial Infarction. Clin Lab 2010;56:303-309.

34. Dzielinska Z, Malek LA, Januszewicz A, Prejbisz A, Pregowski J, Tyczynski P, Makowiecka-Ciesla M, Janas J, Demkow M, Ruzyllo W. Adrenomedullin concentrations at two time points following myocardial infarction and prediction of mid-term outcomes. Arch Med Sci 2011;7:971-976.

35. Tzikas S, Keller T, Ojeda FM, Zeller T, Wild PS, Lubos E, Kunde J, Baldus S, Bickel C, Lackner KJ, Munzel TF, Blankenberg S. MR-proANP and MR-proADM for risk stratification of patients with acute chest pain. Heart 2013;99:388-395.

36. Haaf P, Twerenbold R, Reichlin T, Faoro J, Reiter M, Meune C, Steuer S, Bassetti S, Ziller R, Balmelli C, Campodarve I, Zellweger C, Kilchenmann A, Irfan A, Papassotiriou J, Drexler B, Mueller C. Mid-regional pro-adrenomedullin in the early evaluation of acute chest pain patients. Int J Cardiol 2013;168:1048-1055.

37. Meune C, Balmelli C, Twerenbold R, Reiter M, Reichlin T, Ziller R, Drexler B, Stelzig C, Freese M, Wolf C, Haaf P, Osswald S, Mueller C. Utility of 14 novel biomarkers 
in patients with acute chest pain and undetectable levels of conventional cardiac troponin. Int J Cardiol 2013;167:1164-1169.

38. Kato J, Tsuruda T, Kita T, Kitamura K, Eto T. Adrenomedullin: a protective factor for blood vessels. Arterioscler Thromb Vasc Biol 2005;25:2480-2487.

39. Melander O, Newton-Cheh C, Almgren P, Hedblad B, Berglund G, Engstrom G, Persson M, Smith JG, Magnusson M, Christensson A, Struck J, Morgenthaler NG, Bergmann A, Pencina MJ, Wang TJ. Novel and conventional biomarkers for prediction of incident cardiovascular events in the community. JAMA 2009;302:49-57.

40. McLatchie LM, Fraser NJ, Main MJ, Wise A, Brown J, Thompson N, Solari R, Lee MG, Foord SM. RAMPs regulate the transport and ligand specificity of the calcitoninreceptor-like receptor. Nature 1998;393:333-339. 
